\title{
Ethnic federalism and internal minorities: the legal protection of internal minorities in Ethiopia
}

Fessha, Yonatan Tesfaye and Van der Beken, Christophe

\section{Introduction}

Not a single federal arrangement has been successful in demarcating the territorial matrix of the federation into separate ethnically defined territorial units. The decade-old federal experiment in Ethiopia is no exception to the impractical reality of creating ethnically pure sub-national units. Although the internal structure of the federation, by and large, follows an ethnic line, ethnic minorities are found in the midst of most, if not all, regionally empowered ethnic groups. This has brought to the fore issues about the majority-minority tension at the level of the sub-national units or, as they are called in Ethiopia, regions. The status and treatment of those who do not belong to the empowered regional majority has emerged as a thorny issue that has bedevilled the federal experiment. ${ }^{1}$

The aim of this contribution is to examine whether the federal system adopted in Ethiopia responds adequately to the challenges of internal minorities. It, in particular, examines whether the federal arrangement provides for appropriate institutional solutions to the tensions that exist between regionally empowered groups and their internal minorities. Before discussing the Ethiopian case, however, the article, in the following section, casts the issue in the context of multi-ethnic federations. By doing so, it seeks to show that the problem of internal minorities is not unique to the federal arrangement in Ethiopia.

1. The terms ethnic minorities, intra-substate minorities, internal minorities and minorities within minorities are used interchangeably to refer to those who do not belong to the regionally empowered group. For the sake of brevity and consistency, this article has opted to use the term internal minorities. 


\section{The plight of internal minorities in multi-ethnic}

\section{Federations $^{2}$}

Internal minorities are the common feature of multi-ethnic federations. Englishspeakers in Quebec (Canada), Spanish-speakers in Catalonia (Spain) and Frenchspeakers in Flanders (Belgium) are some of the prominent examples of internal minorities in the literature of multi-ethnic federations. 3 The impractical reality of creating an ethnically or linguistically homogenous sub-national unit has made the accommodation of internal minorities an essential part of the efforts to build a successful federation.

The treatment of internal minorities is one of the tensions that characterises the oldest federation in Africa, Nigeria. This is mostly about the treatment of individuals that are not regarded as indigenous to the state in which they reside. Internal migrants in Nigeria are often subjected to discriminatory policies and laws. The federation has experienced tension and even serious communal violence 'over attempts by indigenes to exclude large, but ostensibly non-indigenous, resident communities from economic and political opportunities controlled by state and local governments'. 4 The multi-ethnic federation of Canada has also been grappling with the problem of internal minorities. This largely pertains to the treatment of English speakers in the French-speaking province of Quebec. The Charter of the French Language in Quebec, which is famously known as Bill 101, is a good example that illustrates this situation. Adopted by the Parti Québécois government in 1977, Bill 101, following the territorial model of language planning, sought to promote the use of French and at the same time restrict the use of English. It obliges both immigrants and Canadians moving to Quebec to send their children to a French school and mandated the display of commercial signs in French only. Although part of this legislation was eventually abrogated by the Supreme Court of Canada, it vividly illustrates the majority-minority tension that characterises Canada and other multi-ethnic federations.

2. This section is partly adopted from a broader work on federalism and internal minorities by Yonatan Tesfaye Fessha.

3. A. Patten, 'The Rights of Internal Linguistic Minorities', in A. Eisenberg and J. Spinner-Halev (eds), Minorities within Minorities: Equality, Rights and Diversity, Cambridge University Press (2005), pp. 135-56.

4. R. T. Suberu, 'Nigeria', in L. Moreno and C. Colino (eds), Diversity and Unity in Federal Countries: A Global Dialogue on Federalism, vol. 7, McGill-Queen's University Press (2010), pp. 227-57. 
Another multi-ethnic federation that is confronted with the problem of internal minorities is the linguistically divided Belgium. When the linguistic border was fixed in 1963 in Belgium, members of the francophone community found themselves demarcated into the Flemish-speaking part of the country. In order to accommodate these internal minorities, 'language facilities' were introduced in Flanders along the language border. In a clear exception to the rule of territoriality and with a view to protecting internal linguistic minorities, these facilities allow individual inhabitants the right to communicate in their own language with a public authority, even if the authority is not from the same linguistic group.

In addition, the local municipality, upon a request from a minimum number of parents, has to offer primary education in the language of the minority group. The problem is that the Flemish tend to see these facilities as transitional measure while the Walloons regard them as permanent component of the institutional organisation that has to accommodate the French-speaking minorities. 5 In the former Yugoslavia, the territorial structure was arranged along ethnic lines but failed to completely coincide territorial boundaries with patterns of ethnic settlement resulting in disgruntled internal minorities. As a result, 'the break up of Yugoslavia has produced unstable successor states with internal minorities, and has led to savage warfare and genocide in the service of ethnic cleansing'. ${ }^{6}$

From the foregoing, it is clear that the need to take into account the interests and rights of internal minorities is particularly important for a multi-ethnic federation. The challenges of accommodating internal minorities are manifest in different aspects of governance. From the above examples, however, it is clear that the plight of internal minorities is often visible in the areas of language policy and education. In states whereby each constituent unit is allowed to promote its own language, the vexing question has been whether internal minorities have to assimilate to the language of the regionally dominant group or should still be allowed to use their own language. Irrespective of the nature of the challenges, the point remains that account must be taken of whether the adopted federal arrangement prejudices the rights and interests of the non-dominant communities within the constituent units. Securing the rights of internal minorities that are created by autonomy arrangements is crucial to the longterm success of any federal arrangement. 7

5. Disagreement continues between the Walloons and the Flemish over the interpretation of the language facilities; see K. Deschouwer, 'Belgium', in J. Kincaid and A. G. Tarr (eds), Constitutional Origins, Structure and Change in Federal Countries: A Global Dialogue on Federalism, vol. 1, McGill-Queen's University Press (2005), pp. 48-76.

6. A. C. Cairns, 'Constitutional Government and the Two Faces of Ethnicity: Federalism Is Not Enough', in K. Knopf, S. Ostry, R. Simeon and K. Swinton (eds), Rethinking Federalism: Citizens, Markets and Governments in a Changing World, University of British Columbia Press (1995), p. 27.

7. Y. Ghai, 'Ethnicity and Autonomy: A Framework for Analysis', in Y. Ghai (ed.), Autonomy and Ethnicity: Negotiating Competing Claims in Multi-ethnic States, Cambridge University Press (2001), pp. 1-28. 
Two-thirds of the 76 million population belong to three major ethnic groups. This is despite the fact that the country is home to no fewer than eighty ethnic groups. The Oromo are the largest ethnic group accounting for 34.49 per cent of the population, followed by the Amhara (26.89 per cent) and the Somali (6.2 per cent). The next four numerically strong ethnic groups are the Tigray (6.1 per cent), Sidama (4.0 per cent), Gurage (2.5 per cent) and Wolayta (2.3 per cent). ${ }^{8}$ With no single ethnic group accounting for the majority of the population, Ethiopia, like most other African states, can be appropriately described as a country of minorities.

To be precise, although all ethnic groups can be designated as ethnic minorities at the federal level, majority-minority relationships characterise most of the regions. This largely has to do with the geographical configuration of the federation. Article 47 establishes nine regions that are largely delimited along linguistic lines: the state of Tigray, the state of Afar, the state of Amhara, the state of Oromia, the state of Somali, the state of Benishangul-Gumuz, the state of the Southern Nations, Nationalities and Peoples (hereafter SNNPR), the state of the Gambella peoples and the state of the Harari people. 9 Although none of the regional states is ethnically pure, a particular ethnic group constitutes a significant numerical majority in each of the first five regions listed above. In fact, each of these regions is also designated after the name of its numerically dominant ethnic group. ${ }^{10}$ Although these five regions are designated as belonging to their respective numerically dominant ethnic groups, they are not ethnically pure. Internal minorities are scattered throughout the regional majorities, giving rise to a majority-minority tension. Neither are the remaining regions immune to the challenges of accommodating internal minorities; as is evident from their names, they, unlike the other regions, have not been designated as belonging to one specific group. With no single ethnic group accounting for the majority of the regional population, ethnic groups living in the three regional states can also be regarded as internal minorities.

Some of the internal minorities are indigenous to the area they inhabit. This, for example, includes ethnic groups like the Kunama in Tigray as well as the Agew and the Oromo, both of which inhabit pockets of the territory of the Amhara regional state. On the other hand, many people are also living outside 'their region', where they consequently constitute an internal minority. These

8 The 2007 Population and Housing Census of Ethiopia: FDRE Population Census Commission, Summary and Statistical Report of the 2007 Population and Housing Census (2008).

9 This is based on article 46 of the constitution, which states that the geographical configuration of the federal state shall be based on 'the basis of settlement patterns, language, identity and consent of the people concerned', indicating that ethnicity constitutes not only one of the major features of the constitution but also the basis for the internal organisation of the federal state.

10 An exception to this is the Harari regional state, which is designated after the Harari ethnic group despite the fact that the Harari constitute a small numerical minority in the Harar region (i.e., they make up barely 10 per cent of the regional population). Yet, the 2004 Harari regional constitution enables the Harari to exercise considerable control over the regional political institutions. The Ethiopian federal constitution grants constitutional autonomy, hence the power to enact their own constitutions, to all regions. All regions have effectively used this power and adopted their own constitutions. 
are individuals that belong to the Amhara and other ethnic groups who have historically moved south and settled in Oromia and other regional states for different historic or economic reasons. This means that at least two types of internal minorities may be identified: indigenous and non-indigenous internal minorities.

The classification of internal minorities into indigenous and non-indigenous finds support in both regional constitutions and their political practice. The term indigenous is, for instance, explicitly used in the Benishangul-Gumuz constitution of 2002 to refer to five ethnic groups: the Berta, Gumuz, Shinasha, Mao and Komo. This is irrespective of the fact that many people belonging to other ethnic groups and that have historically moved to the region also reside in the region, accounting for almost 50 per cent of the regional population. According to the Benishangul-Gumuz constitution, these particular ethnic groups fall under the category of non-indigenous groups.

Other regional constitutions, like the Gambella constitution, use the term 'founder' nations, conveying the same meaning. ${ }^{11}$ The differentiation into indigenous and nonindigenous, founders and others, can be attributed to the 'territorial approach' that the Ethiopian federation has adopted to the challenges of ethnic diversity, which is the hallmark of the Ethiopian federation. When establishing the nine regions, an attempt was made to achieve an overlap between regional borders and ethnic borders. ${ }^{12}$ Each region was conceived as the home of one or several ethnic groups. ${ }^{13}$ Hence, internal minorities living outside the region that is supposed to be theirs are considered as nonindigenous. As the next two sections show, having an indigenous or non- indigenous status has important implications for the legal position of an internal minority.

\section{The legal protection of indigenous internal minorities}

Indigenous internal minorities can claim a wide range of rights based on federal as well as regional constitutions. This is related to the fact that the federal

11 The constitution of Gambella designates the Nuer, Anuak, Mejenger, Upo and Komo as founders of the regional state. This does not include individuals that belong to other ethnic groups and that have historically moved to the region and account for almost 25 per cent of the population.

12 The decision to coincide regional boundaries with ethnic groups can be traced to Proclamation No. 7/1992 of 14 January 1992; a law enacted during the transitional period. With the view to implement an ethnic-based decentralisation programme, the law established fourteen regions. Furthermore, the law listed more than sixty ethnic groups and linked each one of them to one (or in case of the Oromo to two) of the regions. Hence, the law localised the traditional territory of the ethnic groups in one of the fourteen regions. To put it differently, all ethnic groups were considered to be indigenous in one of the fourteen regions. This territorial-administrative set-up was transplanted into the federal constitution although the number of regions was reduced to nine as five of the regions in the south were merged into one to form the SNNPR.

13 The ethno-territorial emphasis can also be inferred from the constitutional right of all ethnic groups to secede from the federation (article 39 federal constitution) as well as from the right of all ethnic groups to establish their 'own' region within the federation (article 47(2) federal constitution). 
constitution provides for a broad spectrum of rights that are relevant for the protection of both individuals that belong to indigenous internal minorities and to the minorities as groups. In other words, both individual and group-specific rights are provided for. Individual rights that are relevant for the protection of persons that belong to indigenous internal minorities include the right to equality and non- discrimination, ${ }^{14}$ freedom of movement and freedom to choose one's residence within the Ethiopian territory, ${ }^{15}$ and the right to vote and to be elected without any discrimination on any grounds including based on ethnic identity. ${ }^{16}$

On the other hand, article 39 of the constitution provides for important group- specific rights, including the right to self-determination. To be precise, four components of the right to self-determination can be identified. First, ethnic groups are granted language rights and cultural rights. Article 39(2) provides that every ethnic group 'has the right to speak, write and develop its own language; to express, to develop and to promote its own culture; and to preserve its history'. Second, every ethnic group is given the right to self-government, which includes an important component of the right to territorial selfrule. In addition, article $47(2)$ of the federal constitution grants all ethnic groups except for the six that already have a 'mother' region - the right to establish their own region. ${ }^{17}$ Third, every ethnic group has the right to be represented in the regional and federal governments. Finally, article 39 grants every ethnic group the right to secede from the federation.

Internal indigenous minorities at the regional level can invoke these rights against the regional government. After all, the federal constitution is the supreme law of the land that has to be respected and enforced both by federal and regional authorities. ${ }^{18}$ In fact, the universal rights recognised by the federal constitution have been almost fully integrated into the regional constitutions. The four-component right to selfdetermination is also included in all regional constitutions. Indigenous internal minorities can, therefore, claim a wide spectrum of universal and group-specific rights based on the federal and their respective regional constitutions.

4 Article 25 federal constitution.

Article 32 federal constitution.

Article 38 federal constitution.

17 Neither the right to secession nor the right to establish a new regional state has so far been exercised. To date, the rights of the indigenous minorities have been exercised within and through the framework of the nine regions established by the federal constitution.

18

Article 9 federal constitution. 
Of course, the recognition of rights is not enough. States need to put in place mechanisms that can ensure the implementation of constitutionally recognised rights. This is especially true with group-specific rights, which, like the individual rights, impose negative obligations on the State but also require the regions to take measures that are necessary to ensure the realisation of these rights. The regional states have, in particular, sought to use the territorial subdivisions of their units to respond to the problem of internal minorities. Furthermore, some of the regional constitutions have complemented these mechanisms with arrangements that allow for equitable representation in the institutions of the regional government. As the ensuing paragraphs amply demonstrate, aspects of both self-rule and shared rule, it seems, form part of the institutional mechanisms that the regional constitutions provide for in order to guarantee the legal protection of indigenous internal minorities.

\section{A. Territorial self-rule for indigenous internal minorities}

Most of the regional governments are comprised of a three-tier local government structure, namely Zone, Wereda and Kebele. With the view to accommodating indigenous internal minorities, several regional constitutions have amended their constitutions to provide for the establishment of ethnically defined Zones, which are hierarchically situated just below the regional government. ${ }^{19}$ The ethnically defined Zones are recognised by their respective regional constitutions as an autonomous tier of local government with constitutionally mandated elected councils and executive administrations.

19 For example, the SNNPR is home to dozens of ethnic groups. In order to respond to the constitutional requirement of ensuring selfgovernment for the different ethnic groups, the regional constitution has established ethnically defined Zonal administrations. The Amhara state has also established three special Zones (or Nationality Administrations) for the three indigenous minorities (i.e., the Agew Himra, Awi and Oromo). Similar administrative entities are provided for the five indigenous minorities in Benishangul-Gumuz. See article 74 Benishangul-Gumuz constitution and Benishangul-Gumuz regional Proclamation No. 73/2008, Lissane Hig Gazeta, 1 November 2008. The Gambella constitution also provides for the establishment of a Nationality Zone for the three indigenous minorities of Anuak, Nuer and Mejenger. 
Several regional states have also established Special Weredas in order to accommodate indigenous internal minorities that, owing to their population size, cannot have their own Zone within a regional state. ${ }^{20}$ In the case of some regional states, even Kebele, the lowest local government unit, is used to address the claims of indigenous internal minorities that are too small in number to have their own Zonal or Wereda administrations. ${ }^{21}$ Simply put, the basic mechanism that the regional states use to implement the rights of indigenous internal minorities is the creation of a separate territorial entity in a form of local government in which the indigenous internal minorities are in a majority. ${ }^{22}$ Functioning as autonomous entities, these ethnically defined local governments (i.e., Zones, Weredas and, in some cases, including Kebele) provide indigenous internal minorities with the territorial space that is necessary to manage their own affairs. They enable the indigenous internal minorities to exercise some measure of self-rule, the degree of which is, of course, determined by the competencies of the particular local government concerned. For instance, Weredas have the power to approve plans of socio-economic development and the corresponding own budget. The Council of the Wereda has also the power to appoint and exercise control over the Wereda executive body. Furthermore, the ethnically defined Zones/Special Weredas allow indigenous internal minorities to protect and promote their language as their respective regional constitutions allow them to choose their own working language.

20 The region with the largest number of Special Weredas is the SNNPR, which has four Special Weredas. The Tigray regional constitution does not provide for a separate territorial entity for the indigenous Irob and Kunama minorities, but in practice a separate Wereda has been established for the Irob. Article 43(2) of the Afar constitution stipulates that the Argoba have a right to a separate Wereda and such a Wereda has effectively been established in the region.

21 In Gambella, for example, the establishment of a Nationality Zone or Special Wereda is not provided for the numerically very small Upo and Komo minorities. However, according to article 47(3) of the Gambella constitution, they, as minority nationalities, have the right to establish their own Kebele. Similarly, the Kunama in Tigray have their own Kebele.

22 As the foregoing would suggest, the arrangements designed for the fulfilment of the right to self- determination are similar in all regions and are reflective of the ethnic-territorial approach that constitutes the central characteristic of Ethiopia's federal experiment. 


\section{B. Representation of indigenous internal minorities in the regional government}

The federal constitution requires the 'equitable representation' of the different ethnic groups in regional governments. ${ }^{23}$ Regional governments are obliged to ensure that the faces of their institutions reflect the ethnic plurality that characterises their society. This, first, applies to regional states that are, more or less, ethnically homogenous but still have some minorities in their midst. This refers to, for example, the representation of the Kunama and Irob ethnic communities in Tigray as well as the Agew Awi and the Oromo in Amhara. Second, and more importantly, it applies to the ethnically heterogeneous regional states like Gambella, Benishangul-Gumuz and SNNPR. In short, it applies to all indigenous internal minorities. Furthermore, the equitable representation of the different ethnic communities is not merely limited to the executive. As the obligation of ensuring equitable representation is mentioned in relation to state and federal governments in general, state governments are obliged to ensure equitable representation in the legislative and judicial arms of state governments as well. The constitutional obligation of equitable representation reflects the constitutional commitment to accommodate intra-regional diversity. By ensuring representation of the different ethnic groups that inhabit the regions, it signals the message that each region belongs to all who live in it. Yet, the realisation of this constitutional mandate depends on the regional constitutions that should give effect to it. The question is then whether regional constitutions and laws have put in place mechanisms that ensure the implementation of this constitutional mandate.

In this regard, the plurality electoral system used in all regions goes a long way in ensuring the representation of most indigenous internal minorities in the regional parliaments. In case indigenous internal minorities are too small to control an electoral constituency, they are treated as minority nationalities and peoples.24 Many of the regional constitutions grant these minorities a special

23 Article 39(3) federal constitution. This constitutional mandate applies to the federal government as well.

24 Article 2(6) Proclamation No. 7/1992, Negarit Gazeta, 14 January 1992 and article 20(a)-(d) Electoral Law of Ethiopia Amendment Proclamation No. 532/2007, Federal Negarit Gazeta, 25 June 2007. 
representation in the form of a quota in their respective regional parliament. ${ }^{25}$ With regard to the executive, the regional constitutions, with the exception of one regional constitution (i.e., the constitution of Harar), do not provide an explicit guarantee of ethnic representation. In practice, however, the composition of almost all regional governments reflects a fair representation of their respective indigenous internal minorities. ${ }^{26}$ The interest of indigenous internal minorities is also taken into account in the composition of the regional judiciary. Ethnic Zones are given the right to advise the regional parliament on the appointment of judges. Furthermore, indigenous internal minorities have a constitutionally guaranteed representation in the regional institutions that are responsible for interpreting their respective constitutions. ${ }^{27}$ The regional bodies that are responsible for interpreting their respective constitutions include a representative either from each Wereda or at least from each ethnically defined Zone and Special Wereda. ${ }^{28}$

From the foregoing, it is clear that the Ethiopian constitutional framework provides for a number of mechanisms to protect the interests of indigenous internal minorities. In line with the ethno-territorial approach that underlies the federal arrangement, the major mechanism for the protection of indigenous internal minorities involves the creation of separate ethnic-based territorial administrations within which the indigenous internal minorities concerned can exercise self-government and other minority rights. This is complemented by a constitutional instruction that each regional government must ensure the equitable representation of the different ethnic communities. As the following sections

25 Article 45(3) Amhara constitution; article 48(2) Benishangul-Gumuz constitution; article 50(2) Gambella constitution; article 50(2) Southern constitution.

26 C. Van der Beken, Unity in Diversity - Federalism as a Mechanism to Accommodate Ethnic Diversity: The Case of Ethiopia, Lit Verlag (2012), p. 289.

27 The Ethiopian Constitution is unique in that the power to interpret the constitution and to rule on issues of constitutionality is not left to the courts but rather to a political body. Almost all regional constitutions, with the exception of the constitution of the Southern region (SNNPR), emulate this model and provide for the establishment of a specific Constitutional Interpretation Commission.

28 For example, the Afar constitution stipulates that the Constitutional Interpretation Commission shall be composed of representatives from each Wereda Council in the region (article 70(1) Afar constitution). The territorial organisation of the region, which establishes a specific Wereda for the Argoba, the only indigenous internal minority in the region, ensures the representation of the latter in the Commission. Article 68(1) of the Tigray constitution provides that members of the Commission shall include representatives from each Wereda Council (thus including an Irob representative) as well as the representatives of the region in the House of the Federation (which includes one Irob and one Kunama representative). On the other hand, the constitutions of the Amhara, Benishangul-Gumuz and Gambella regions ensure the representation of the indigenous minorities in the Commission by including representatives from the ethnically defined Zones, alternatively known as Nationality Administrations, administrative units that, as indicated earlier, are established for their respective indigenous internal minorities. Article 70(1) of the Amhara constitution states that the members of the Constitutional Interpretation Commission are to be drawn from each and every Nationality and Wereda Council. Article 71(1) of the Benishangul-Gumuz constitution guarantees an equal representation of all indigenous minorities in the Constitutional Interpretation Commission. More specifically, it says that each indigenous nationality shall have four representatives. These four representatives shall be elected by the Councils of their territorial-administrative entities: the Council of the Administration of Nationalities. The Constitutional Interpretation Commission in the Gambella region is similarly composed of representatives of each (of the three) Councils of Nationality Zone. 
will reveal, however, non-indigenous minorities do not enjoy the same level of protection. The legal status of non-indigenous internal minorities is the focus of the next section.

\section{The legal protection of non-indigenous internal minorities}

As indicated earlier, although the majority of non-indigenous internal minorities belong to the Amhara ethnic group, individuals that belong to other groups, who nevertheless speak Amharic, are also widely scattered throughout the country. They are usually found in large number in major urban areas. Owing to their settlement pattern, territorial selfrule is not feasible for these minorities.

The settlement pattern of non-indigenous internal minorities suggests that they must seek protection within a non-territorial framework. One such mechanism that is often used to protect minorities relates to a constitutionally entrenched list of individual rights, commonly known as a bill of rights. Individual rights, as indicated earlier, form a major part of both the federal and regional constitutions. This is clearly stated from the outset in the preamble to the constitution, which emphasises the 'full respect of individual and people's fundamental freedoms and rights'. It also declares the need to 'live together on the basis of equality and without any sexual, religious or cultural discrimination'. As mentioned earlier, the constitution also provides for a vast array of universal individual rights. Importantly, article 25 of the constitution declares the right to equality and prohibits discrimination on grounds of, among other things, race, nation, nationality, or other social origin, language, religion or other status. Of course, individuals that belong to non-indigenous internal minorities can - as any other citizen - claim these individual rights. For instance, citizens with an Amhara identity cannot be denied the right to move to the Oromia region ${ }^{29}$ and neither can they be denied the right to vote and to be elected to regional parliament. In general, members of nonindigenous internal minorities have the right not to be discriminated against by the regional government. ${ }^{30}$ This means that effective protection of individual rights would go a long way in protecting and promoting the rights and interest of persons that belong to non-indigenous internal minorities. The practice does not, however, reflect the equal status that the constitution bestows on individual and collective rights. As argued elsewhere, the major challenge in terms of accommodating non-indigenous internal minorities is attributable to a political practice that gives more weight to collective rights and frustrates claims based on individual rights. For example, there are cases where the language issue has often been used to block non-indigenous internal minorities from exercising their individual rights to participate in the political institutions of the regional states. More specifically, in some regions, individuals that do not speak the working language of the region are barred from contesting elections. As

29 Article 32 federal constitution and Oromia constitution

30 Article 25 federal constitution and Oromia constitution.

\section{http://repository.uwc.ac.za}


a result, the political participation of non-indigenous internal minorities in state administration has been largely curtailed. This contradicts article 38 of the federal constitution, which declares the right of every Ethiopian national to take part in the conduct of public affairs, including to vote and to be elected at periodic elections, without any discrimination based on nation, nationality, language, religion or other status. In fact, the right of individuals that belong to non-indigenous internal minorities to stand for election was at the centre of a case that was brought before the House of Federation, the second chamber of the Ethiopian parliament that has the unique responsibility of interpreting the constitution and ruling on the constitutionality of laws. In that case, three Amharic-speaking individuals belonging to non-indigenous internal minorities wanted to stand for the 2000 state legislature election in BenishangulGumuz regional state. $3^{1}$ A decision of the National Electoral Board (NEB) denied the individuals the right to stand for election on the ground that they could not communicate in any of the four indigenous languages spoken in the region. The decision of the NEB was later reversed by the House of Federation. Although the decision of the House affirmed the right of the individuals to contest the election, it has not confirmed the right of individuals to stand for an election irrespective of their linguistic ability. The House rejected the decision of the NEB on the basis that the individuals can speak the working language of the region, which happens to be Amharic, and do not necessarily have to speak the languages of any of the indigenous groups. It held, however, that the electoral law that makes the right to stand for an election dependent on the ability to speak the working language of the region is constitutional. This represents a legal endorsement of the political practice that denies individuals that belong to nonindigenous internal minorities the right to exercise their political rights in regions that do not use Amharic as their working language, thereby relegating them to second-class citizens. Considering the frustration of claims based on individual rights, one wonders whether non-indigenous internal minorities can rely on group-specific rights to protect the rights and interests of their members. A brief survey of the regional constitutions would reveal that the provisions of the multi-faceted group-specific right of selfdetermination are either expressly or implicitly limited to indigenous internal minorities. Article 8 of the 2001 Oromia constitution grants sovereign power exclusively to the 'people of the Oromo Nation' and the constitution, under article 39, reserves the right to self-determination to the 'people of the Oromo nation'. This suggests that the right to exercise self-determination, as provided by the regional constitution, is the preserve of the 'Oromo people', excluding a large number of non-indigenous minorities from the constitutional promise of the right to self-determination. Similar provisions are included in articles 9(1) and 39 of the 2002 Somali constitution. Furthermore, most of the regional

31 Benishangul-Gumuz is home to four major indigenous ethnic groups. It is also inhabited by a very large group of Amhara and other Amharic-speaking individuals from other ethnic groups. The working language of the region is Amharic. 
constitutions and their laws have limited the establishment of ethnically defined Zones and Special Weredas to indigenous internal minorities. ${ }^{2}$ As indicated earlier, the creation of such separate sub-regional territorial units in which the minority concerned is in a majority is the mechanism that is used to realise the right to selfdetermination of indigenous internal minorities. Insofar as the right of representation in regional government institutions is concerned, no specific mechanisms are provided either. Non-indigenous internal minorities are not represented in the regional parliaments. Of course, as any Ethiopian citizen, they have the right to vote and to be elected into regional parliaments. The right to be elected is, however, dependent on the candidate knowing the regional working language, 33 which, as indicated earlier, has proved to be an obstacle for the election of individuals belonging to non-indigenous internal minorities. Neither can the nonindigenous internal minorities claim a representation in the regional institutions that are responsible for constitutional control.

\section{Vi. Improving the legal status of non-indigenous internal minorities}

Although non-indigenous internal minorities might be entitled to claim the minority rights provided by article 39 of the federal constitution, the foregoing discussion has demonstrated that no constitutional mechanisms have been designed to guarantee the enforcement of these rights. Based on these observations, we will now consider a number of constitutional/administrative arrangements that can be used to address the concerns of individuals belonging to non-indigenous internal minorities. The next section commences the discussion by examining the option of non-territorial autonomy.

\section{A. Granting non-territorial autonomy 34}

The mechanism of non-territorial autonomy deviates radically from the ethnoterritorial approach that characterises the Ethiopian federal system. Non-territorial autonomy entails the establishment of legislative and executive councils that are not linked to a particular territory. The authority of these institutions will be limited to the members of the concerned ethnic group but will extend to all

32 The Amhara, Gambella and Benishangul-Gumuz constitutions as well as laws limit the establishment of a Nationality Administration/Zone to the indigenous minorities. Although the constitution of SNNPR does not explicitly exclude nonindigenous minorities from the establishment of Zones/Special Weredas (article 45(2) Southern constitution), no ethnic Zones/Special Weredas were created to date for non-indigenous minorities. Of course, it must be added that the geographical settlement of most non-indigenous internal minorities, which are ethnically dispersed, means the territorial approach is not an option that is always available.

33 Article 45(1)(b) Electoral Law of Ethiopia Amendment Proclamation No. 532/2007, Federal Negarit Gazeta, 25 June 2007.

34 A detailed discussion on the application of non-territorial autonomy in Ethiopia can be found in C. Van der Beken, 'Minority Protection in Ethiopia-Unraveling and Improving Ethnic Federalism', Recht in Afrika (2010): 243-73. 
members of the group, irrespective of where they live in Ethiopia.35 Autonomy is therefore linked not to a territorial administration but to the ethnic group concerned. 36

The suggestion here is to complement territorial institutions with non- territorial institutions. Powers could be allocated between both territorial and non-territorial institutions. This would mean that identity related matters, such as language, culture and education, which are now under the jurisdictions of territorial institutions (i.e., regions/Nationality Administrations/ethnic Zones/ Special Weredas) can be exercised by non-territorial institutions in which only members of the particular non-indigenous internal minority are represented. Powers that are territorial because of their very nature - such as trade, police, land policy, agriculture and infrastructure - would continue to be under the authority of the territorial institutions. Nevertheless, the territorial institutions would continue to have the power to determine their working language. This is obviously because the best protection for a language remains its use by public authorities acting for and on behalf of a territorial unit. 37

Although non-territorial autonomy stands in sharp contrast to the ethnoterritorial solution that represents the hallmark of the Ethiopian federation, the concept and application of non-territorial autonomy are not completely alien to Ethiopian federalism. A good example of non-territorial autonomy (but probably for a different purpose) comes from the constitution of one of the nine regions, namely the Harar regional constitution of 2004. Like all regions, the Harar region has a regional parliament. But unlike other regions, the parliament in Harar is

35 In the 1990s, different countries employed the concept of non-territorial autonomy in their institutional organisations (e.g., in Estonia, Latvia, Slovenia and Russia). Currently, the concept of non-territorial autonomy is evident in the division of the federation of Belgium into communities and regions. The Constitution recognises three communities: Flemish, French and German. The three regions include the largely Dutch-speaking Flemish, the French-speaking Walloon and Brussels. The functions and responsibilities of the communities are related to the protection of the linguistic identity of their respective communities. As a result, the communities are responsible for education, cultural issues, person-related affairs (like health, social welfare and the like), and the use of language for the purposes of administration, education and social relations. It must be noted that there is no complete territorial overlap between the communities and the regions. Hence, the laws of the Walloon region have no legal force in the bilingual region of Brussels. On the other hand, the decrees of the Flemish and French community apply in the Dutch- and French- speaking regions respectively. More importantly for our purpose, the laws of the communities, it must be noted, apply on the institutions established in the bilingual region of Brussels which, on account of their activities, must be considered as belonging exclusively to one community or the other. In practice, this means that the Dutch speakers in Brussels resort to the authority of the Flemish community, just like the inhabitants of the Flemish region. The same goes for the French- speaking residents of Brussels. The role of the communities in Brussels forms a clear application of the concept of non-territorial autonomy. For more, see Van der Beken, Unity in Diversity, supra note 26.

36 J. McGarry, 'Federal Political Systems and the Accommodation of National Minorities', in A. L. Griffiths and K. Nerenberg (eds), Handbook of Federal Countries, 2002, McGill-Queen's University Press (2002), p. 425.

37 J. McGarry and M. Moore, 'Karl Renner, Power Sharing and Non-territorial Autonomy', in E. Nimni (ed.), National Cultural Autonomy and its Contemporary Critics, Routledge (2005), p. 84.

\section{http://repository.uwc.ac.za}


composed of two houses. $3^{8}$ One of these houses is the Harari National Council, a second chamber of the regional parliament. The Council is exclusively composed of Harari representatives that are elected not only by Harari living in the region but also by those living in other parts of Ethiopia. 39 The Council is thus the representative institution of all Harari living in Ethiopia, making it a non-territorial institution. The powers of the Council are limited to issues that are directly related to the protection of the identity of ethnic Harari in areas of language, culture and history. 40

Another non-territorial autonomy arrangement has recently been introduced in the Benishangul-Gumuz region. As mentioned earlier, the regional constitution provides for the establishment of the Nationality Administration (alternatively known as Zone), an ethnic-based territorial administrative entity that, as indicated earlier, is hierarchically situated just below the regional level. Based on this, a law enacted by the regional parliament has established five Nationality Administrations, one for each of the indigenous internal minorities. ${ }^{41}$ Notably, the Proclamation does not limit the powers of these administrations to their respective territories. For certain issues, the administrations will have extra- territorial powers, albeit within the boundaries of the region. Article 3(4) of the Proclamation stipulates that the Nationality Administration is established bounderless regarding the protection and preservation of the rights and privileges of nationality cases ... '. Nationality cases, according to the Proclamation, are cases related to language and history. The Nationality Administration will thus be competent to protect the language and cultural rights of members of the ethnic group on whose behalf it is established, irrespective of the fact that the members live outside their zone or traditional homelands. Such a system, obviously, offers a mechanism to protect the language and cultural rights of indigenous internal minorities who live outside the boundaries of their own sub-regional unit.

To conclude, granting the option of non-territorial autonomy to all ethnic groups in Ethiopia would provide non-indigenous internal minorities with a mechanism to protect and promote their language and culture; however, the exercise of nonterritorial autonomy within a region or sub-regional administration must be dependent on the community exceeding a certain numerical threshold. It must also be noted that territorial and non-territorial approaches to ethnic diversity are not mutually exclusive.

\section{B. Shared rule at the regional level}

Although the application of non-territorial autonomy would contribute to a better protection of non-indigenous internal minorities, the position of the latter, insofar as territorial issues are concerned, will still be affected by the decisions of

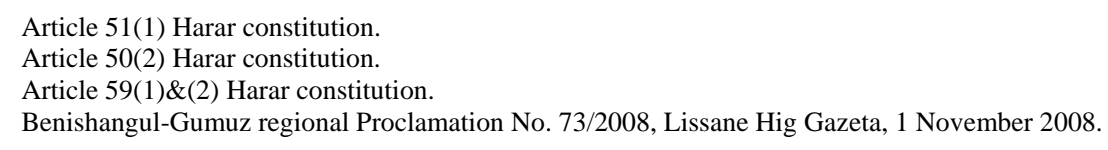


the territorial institutions that represent the regional government. Furthermore, simply granting non-territorial autonomy to non-indigenous internal minorities without measures that would bring the communities into the regional decision- making process might alienate them from the regional or sub-regional majority and thus undermine inter-ethnic integration, which is a necessary condition for the successful accommodation of ethnic diversity in any federation including Ethiopia. $4^{2}$ In order to protect the interests of non-indigenous internal minorities against majority decisions as well as to promote inter-ethnic cooperation and integration, mechanisms of power sharing at regional and sub-regional level must therefore be developed. Such mechanisms could take the form of representation of non-indigenous internal minorities in regional and sub-regional parliaments/councils and institutions responsible for constitutional interpretation. This guaranteed representation can be further complemented with the right of non-indigenous internal minorities to veto decisions that impact upon their fundamental interests. Here also, the workability of the system necessitates numerical thresholds. A viable option could be to link the right to guaranteed representation with the right to exercise non-territorial autonomy.

\section{Establishing multi-ethnic city administrations}

As indicated in the preceding sections, the use of ethnicity to organise the Ethiopian federation has not resulted in the creation of ethnically homogenous territories, be it at the regional or sub-regional level. In the ethnically defined regions, there are ethnic minorities that are politically and, in most cases, numerically dominated by the nominal ethnic groups. However, this observation does not necessarily apply to most cities that are located in these ethnically defined regions. Ethiopian cities are particularly multiethnic and often the nominal or indigenous ethnic group(s) does not account for the majority of the town's population. 43 Despite this fact, the nominal ethnic groups are often politically dominant. Individuals that do not belong to the regionally empowered group or those that do not speak the regional working language are largely excluded from political participation and representation. More specifically, they cannot stand for election or run for regional councils. This has been the cause of grievances among the majority of individuals that account for the numerically significant part, if not the majority, of the population in these ethnically mosaic cities. Very recently, however, the regional parliaments, taking this fact into account, have enacted city proclamations, giving a specific status and some level of autonomy to cities across the country.

42 R. Baubock, Multinational Federalism: Territorial or Cultural Autonomy?, Willy Brandt Series of Working Papers in International Migration and Ethnic Relations, November 2001, available at http://dspace.mah.se:8080/bitstream/2043/690/1/Workingpaper201.pdf (accessed 4 February 2011).

43 For the ethnic composition of the cities in the Oromia and Southern regions see: Central Statistical Authority, The 1994 Population and Housing Census of Ethiopia Results at Country Level Volume II Analytical Report - Results for Oromia Region - Results for Southern Nations, Nationalities and Peoples' Region, CSA (1995). Data from the latest Population and Housing Census of 2007 confirm this trend.

\section{http://repository.uwc.ac.za}


The question is whether these proclamations address the concerns of the urbanites that do not belong to the regionally empowered group.

In 2003, the Oromia regional parliament enacted Proclamation No. 65/2003, which was later revised by Proclamation No. 116/2006 of July 2006.44 These proclamations grant cities an important degree of autonomy. According to these proclamations, cities are administered based on the council-mayor system, in which the city council is vested with the final authority on urban issues while the highest executive power rests with the mayor and the mayoral committee. 45 Members of the council are directly elected by the residents of the city. ${ }^{46}$ Cities, according to the proclamation, are entitled to adopt and execute economic and social development plans, adopt the budget of the city, administer urban land, and enter into contract and cooperation agreements with different stakeholders, including the regional government, the private sector, mass organisations and other cities. 47 A similar city proclamation has been enacted by the SNNPR regional parliament. 48

The creation of autonomous city administrations offers non-indigenous internal minorities that are a numerical minority at the regional level but a numerical majority in the city an important opportunity for political participation and representation. In the Southern region, for instance, the autonomous city administration is particularly important as it offers an opportunity for self- administration to non-indigenous internal minorities that, in most of the towns, account for the majority of the population. For instance, the Sidama ethnic group make up a clear majority in the Sidama Zone; however, in towns located in the Sidama Zone, such as Hawassa and Yirgalem, the Sidama constitute a numerical minority while the non-indigenous internal minorities account for the majority of the cities' population. 49 This means the application of the City proclamation offers individuals that do not belong to the Sidama ethnic group an important opportunity for political representation and significant participation in the city administration. Two important points must, however, be noted. First, the city councils, in some cases, are made directly accountable to the regional government. $5^{0}$

44 Proclamation No. 116/2006, Megeleta Oromia, 12 July 2006

45 Article 11 Oromia Proclamation No. 65/2003.

46 Article 13(1) Oromia Proclamation No. 65/2003. A similar city proclamation in the SNNPR states that the mayor is elected by and from among the members of the City Council (article 16(1)(a) Southern Proclamation No. 51/2002). For more see Proclamation No. 51/2002 of August 2002.

47 Article 8 Oromia Proclamation No. 65/2003

48 Proclamation No. 51/2002 of August 2002.

49 Central Statistical Authority, The 1994 Population and Housing Census of Ethiopia-Results for Southern Nations, Nationalities and Peoples' Region, supra note 43.

50 See article 16 Oromia Proclamation No. 65/2003. 
Second, some of the initial steps taken to grant some level of autonomy to the city administrations have been reversed. In the case of Oromia, for example, although Proclamation No. 65/2003 initially provided that the mayor was elected by the city council,51 this was later amended by article 6 of Proclamation No. 116/2006, which leaves the appointment of the mayor of big cities to the discretion of the regional president. Yet, as opposed to the cities in Oromia, the mayors of the Southern cities, according to the Southern proclamation, are still elected by and from among the members of the city council. $5^{2}$

It is important to note that despite the participation and representation opportunities that these city administrations provide to individuals belonging to non-indigenous internal minorities, they do not go without providing protection to indigenous ethnic groups. In fact, according to most of these proclamations, ethnic groups that are indigenous to a particular city enjoy a specific legal protection. In Oromia, the city proclamation states that where the Oromo constitute a minority in a given city, the regional executive council may reserve up to 30 per cent of the city council seats to the Oromo.53 A similar provision - guaranteeing 30 per cent of the city council seats to the indigenous ethnic group - is included in the SNNPR city proclamation. 54 A legislative amendment in Oromia has even further strengthened the position of the indigenous Oromo in the cities. It has done so not only by making, as indicated earlier, the appointment of the mayors of the largest cities the discretion of the regional president, but also by increasing the percentage of council seats reserved to members of the indigenous ethnic group (namely the Oromo) from 30 per cent to 50 per cent.

The autonomous or rather semi-autonomous city administrations allow individuals that belong to non-indigenous internal minorities to manage their own affairs without seriously undermining the rights of the indigenous ethnic groups. It is, however, obvious that some level of reluctance is evident on the part of the regional governments in offering autonomy to city administrations and thereby guaranteeing non-indigenous minorities full control over their own affairs. This is evident in the fact that the city council, in some cases, is made directly accountable to the regional government. The appointment of mayors by regional administrations is another indication. This upward accountability betrays an image of regional governments that are wary of their respective non-indigenous internal minorities; regional governments that are not yet fully committed to ensuring adequate protection to non-indigenous internal minorities. In any event, these measures that somehow are providing for semi-autonomous city administrations represent a move in the right direction.

5 Article 14(2)(g) Oromia Proclamation No. 65/2003.

52 Article 16(1)(a) Southern Proclamation No. 51/2002.

53 Article 13(3) of Proclamation No. 65/2003.

54 Article 15(1)(a) of Proclamation No. 51/2002 of the SNNPR.

\section{http://repository.uwc.ac.za}




\section{Conclusion}

An effective response to the plight of internal minorities requires regional states to come to terms with their ethnic diversities and fully accept that they are sharing with the federal state the same challenges of accommodating ethnic diversities but only at a regional level. The Ethiopian institutional response to the anxieties of indigenous internal minorities, which involves both territorial self-rule and representation in regional institutions, is in line with this normative position. At the centre of this institutional response is the creation of separate

ethnic-based territorial administrations within which the indigenous internal minorities can exercise self-government and other minority rights. Evidently, this constitutional option is not usually available for non-indigenous internal minorities that are often geographically dispersed. Some of the mechanisms to accommodate non-indigenous minorities must thus be sought within the territorial administration in which these minorities find themselves. Judicially enforceable universal individual rights represent one such response. In this regard, although the constitutional commitment to the observance of full respect to individual and collective rights is an important mechanism that can be used to protect individuals belonging to these particular groups, the practice, it is observed, is not encouraging. The disenfranchisement of non-indigenous minorities, which has relegated them to 'secondary citizens' of the regions, is testimony to a constitutional practice that has failed to give effect to this constitutional commitment. Furthermore, the lack of protection in the form of non-territorial autonomy means that non-indigenous internal minorities, who are often 'too dispersed or few in numbers' to exercise territorial autonomy, are denied a say in matters that are relevant to them. It is clear, therefore, that comprehensive minority protection in Ethiopia requires the design of complementary constitutional and legal mechanisms through which non-indigenous internal minorities can exercise some measure of control over matters that are relevant to them. 